\title{
Twentieth Annual Southwest Labor Studies Conference
}

\author{
Chuck Carlson and Kristal Edwards
}

University of California, Santa Cruz

On April 29 and 30, 1994, 350 academics, students, labor activists, and rank-and-file workers converged on the campus of the University of California, Santa Cruz, for the Twentieth Annual Southwest Labor Studies Conference. The theme of the conference was "Race, Ethnicity, and the American Labor Movement." Though theoretical and practical syntheses of the issues of race, gender, and class continue to challenge the energies and imaginations of activists and scholars, this conference achieved an important goal-the extension of communication between labor activists, scholars, students, and workers. The conference was infused with energy. Labor activists and workers compared and evaluated their organizing efforts in light of current research and theory on race, ethnicity, and the labor movement. In their interactions with worker and activists, scholars were poignantly reminded that the labor movement is an ongoing struggle for the quality of life, civil rights and political empowerment of working people. A sense of urgency and historical relevance prevailed, culminating in a dynamic example of what can be learned and built upon when academics, activists, and rank-and-file workers combine their efforts.

General session addresses of Michael Honey of the University of Washington and labor activist María Elena Durazo, president of HERE, Los Angeles Hotel and Restaurant Workers, Local Number 11, as well as the commentary of Clayborne Carson, emphasized the historical relationship between labor, race, and gender in the experiences and identities of working people in the United States, thereby unifying the diverse subjects of workshops, sessions, and panel discussions. Opening his address by singing Big Bill Brunsey's 1940 labor song, "If You're White, Alright; If You're Brown, Stick Around; but if You're Black, Get Back," Michael Honey dramatized the fact that "working people know what academics take years to find out." Honey encouraged the cross-fertilization of activism and labor studies, as he recounted his work as a civil rights and labor organizer in Memphis during the 1970s. He then distinguished current efforts to reconcile race, ethnicity, and gender as closely related fields of study in the making of the American working class from past labor studies. Despite the legacies and realities of a "racial-economic" system that complicate the construction of workers' identities along class lines, Honey put forth a record of successful organizing of workers across racial lines through the civil rights movement and past union struggles. Furthering Honey's message, Clayborne Carson illuminated the problem of the construction of identity as a crucial juncture between the study of labor history 
and modern labor movements and considered the possibility of developing a mass identity through life-long activism.

This questioning of identity was repeated by participants in sessions and panel discussions on global restructuring, the shift from industrial and service economies, the feminization of the labor force, and the challenges of organizing multiracial groups of immigrant workers and cross-border networking of workers in multinational industries.

María Elena Durazo supplied a sense of immediacy to the historical examinations of race and ethnicity in her account of the campaign to organize workers in multinationally owned hotels in downtown Los Angeles. The campaign, which achieved 100 percent union membership in less than five years, relied upon the mobilization of Mexican-, Asian-, and African-American workers and their communities. Her talk electrified conference participants and was accompanied by the video "City on the Edge." The video, produced by Local 11, graphically portrayed the tourist industry and the experiences of service workers in Los Angeles. Durazo attributed union recognition in part to the nationwide distribution of the video.

Durazo's challenge hit home, as spirited exchange brought a pragmatic focus to the studies and experiences of racial and gender realities of work and labor organizing in the Southwest. The sessions "New Perspectives on the Great Upheaval: Ethnicity, Gender, and Race," "Immigrant Miners and their Union Activities in the Southwest, 1896-1920," "American Dockworkers in the Twenticth Century," "Ethnic Labor on the Railroads," and "African American Workers in the Twentieth Century" explored the manipulation of racial identity and ideology, interracial radicalism in labor movements, and the disparate experiences of men and women in these industries.

Legacies of activism and scholarship were extolled and critiqued in panel discussions on "Alexander Saxton's Work on White Working-Class Racism" and "The Legacy of Cesar Chavez." In the latter session, Richard A. Garcia contrasted the historical fictions and interpretations associating Chavez with Mexican cultural and political traditions and Chicano nationalism to Chavez's own definition of activism-rooted in a philosophy of universal human rights, committed to nonviolence, and rejecting materialism. Frank Bardacke stressed the challenge of learning from the legacy through the critical analysis of the history of Chavez and the United Farm Workers (UFW). He presented Chavez's use of the "boycott" as being his greatest legacy, as well as a serious weakness of UFW organizing strategies into the late 1970s and 1980s. He challenged the myth that Chavez taught farmworkers how to be militant and criticized UFW publicity strikes, the union's stance against undocumented workers, and its undemocratic structure.

Panel sections, seminars, and workshops were enlivened by the contributions of workers active in labor struggles, past and present. In a session 
on the successes and failures of the Communist party and the $\mathrm{CIO}$ in campaigns to organize Chicano workers in Los Angeles during the 1930s and 1940s, two CIO members directly challenged presenters' conciusions, expressing their first-hand knowledge of a particular party member as being a "union man first." Several sessions such as "Work, Family and Labor Activism among Women Workers" and "Gendered Images and Perceptions of Women Workers," and the workshop on "The Influence of 1960s Social Movements on Women's Participation in the Labor Movement" examined gendered notions of work and the labor movement, as well as representations of women's participation in the labor movement and female worker activism. These sessions benefited significantly from activists and workers such as Neshty Crudup of IBEW Local 11, who helped break the gender barrier in the electrical industry, and Esperanza Torres, a rank-and-file leader in the 1985-87 Watsonville cannery strike. The panel discussion "Strength in Unity: Ethnic Coalitions and Organizing Immigrant Workers in the 1990s" was energized by the strategies and experiences of community organizers for Janitors for Justice and the Campaign for Justice, who discussed their innovative corporate campaigns and community organizing strategies.

Some workshops and panel discussions were devoted to the practical uses and effectiveness of film, media technology, video, and computer networks in integrating labor studies and organizing. Conference participants viewed and discussed the screenings of the films At the River I Stand and Watsonville on Strike. The workshop on "Technology and Labor Communication: The New Mix" provided practical information on the use of mass media, such as PBS, interactive and cable access television, video production, and the LABOR NET and H-LABOR computer networks. H-LABOR, a network accessed by labor historians worldwide, is moderated by Seth Wigderson, University of Maine. Other sessions explored how computer systems and databases could be used by workers, scholars, and activists to develop studies in support of their research and activism, and in furthering the links between labor and environmental movements. Andrew Szasz and Michael Meuser provided an excellent example of this in their presentation on the disproportionate distribution of toxics produced in the working-class neighborhoods of Los Angeles.

Conference participants carried away a renewed sense of community, mission, and an appreciation of what can be accomplished when the borders between academia and the labor movement are breached. For more information on the conference, contact:

David Brundage

Community Studies Board

College Eight

University of California

Santa Cruz, CA 95064 